\title{
Pengembangan Produk Penyedap Rasa dan Tepung Jamur Tiram di Desa Penambangan dan Kelurahan Dabasah Kabupaten Bondowoso
}

\author{
Indah Yulia Ningsih ${ }^{1}$, Ika Barokah Suryaningsih ${ }^{2}$, Ema Rachmawati ${ }^{1}$ \\ ${ }^{1}$ Faculty of Pharmacy, Universitas Jember \\ ${ }^{2}$ Faculty of Economics and Business, Universitas Jember \\ indahyulianingsih.farmasi@unej.ac.id
}

\begin{abstract}
Abstrak
Jamur tiram merupakan salah satu hasil pertanian yang diminati masyarakat. Banyaknya petani jamur tiram menyebabkan sulitnya harga komoditas ini bertahan bila seringkali terjadi panen raya secara bersamaan. Di Kabupaten Bondowoso, tepatnya di Desa Pertambangan dan Kelurahan Dabasah telah dilakukan budidaya oleh kelompok petani. Namun, para petani jamur tiram tersebut tidak memiliki pengetahuan, dan keterampilan untuk menghasilkan produk olahan jamur tiram yang tahan lama dan memiliki nilai jual yang tinggi. Oleh karena itu, pada kegiatan pengabdian ini dilakukan penyuluhan dan pelatihan mengenai pembuatan dan pengemasan produk olahan jamur tiram dalam bentuk penyedap rasa dan tepung jamur tiram. Adanya diversifikasi produk berperan dalam meningkatkan nilai tambah komoditas jamur tiram, sehingga dapat meningkatkan pendapatan para petani.
\end{abstract}

Kata Kunci: Jamur Tiram, Penyedap Rasa, Tepung Jamur, Pengembangan Produk

\section{PENDAHULUAN}

Jamur tiram (Pleurotus ostreatus) adalah salah satu jamur kayu yang tidak asing bagi masyarakat Indonesia. Jamur ini mudah dibudidayakan karena memerlukan teknologi yang sederhana, dan waktu budidaya yang singkat (Kementan RI, 2011). Jamur tiram banyak diminati masyarakat, sehingga permintaannya di pasaran meningkat. Hal tersebut memicu munculnya usaha budidaya jamur tiram di berbagai daerah, seperti di Kabupaten Bondowoso, Jawa Timur. Kelompok petani jamur tiram yang ada di Kabupaten Bondowoso diantaranya adalah kelompok petani "Penambangan" yang ada di Desa Penambangan, Kecamatan Curahdami dan kelompok petani "Veteran" yang ada di Kelurahan Dabasah, Kecamatan Bondowoso.

Pada kondisi tertentu, produktivitas jamur tiram yang terlalu tinggi dapat menimbulkan kesulitan tersendiri. Musim penghujan dengan kelembapan tinggi akan menyebabkan pertumbuhan jamur tiram sangat pesat, sehingga kerap terjadi panen raya. Selain itu, bila baglog yang digunakan masih baru atau ketika memasuki tahap panen awal, maka biasanya hasil panen akan mencapai puncaknya. Ketika jumlah jamur tiram yang ada di pasaran sangat melimpah akibat panen raya bersamaan, maka harga jual menurun menjadi Rp. 7.000,- hingga Rp. 9.000,-/kg. Apalagi kedua mitra masih memiliki area pemasaran yang terbatas, yaitu di pasar induk Bondowoso dan sekitarnya. Akibatnya, petani terpaksa menjual hasil panennya dengan harga rendah untuk menghindari kerugian lebih besar karena jamur tiram tidak dapat disimpan lama, baik pada suhu ruang maupun dalam lemari pendingin. Jamur tiram yang berumur lebih dari 1 hari setelah panen tidak akan laku dijual.

Untuk mengatasi masalah mitra terkait daya tahan jamur tiram yang rentan terhadap kerusakan, maka perlu dilakukan diversifikasi pengolahan jamur tiram dan pengembangan teknologi olahannya dalam rangka meningkatkan nilai tambah jamur 
tiram segar. Pengolahan komoditas jamur tiram menjadi berbagai macam produk menjadikan daya simpannya lebih lama dan jangkauan pemasarannya lebih luas. Contoh bentuk produk olahan jamur tiram adalah penyedap rasa dan tepung jamur tiram.

Banyaknya efek samping akibat penggunaan penyedap rasa yang mengandung monosodium glutamat (MSG) menyebabkan potensi jamur tiram sangat tinggi untuk diolah menjadi produk penyedap rasa karena mengandung asam glutamat tetapi rendah sodium dan kalium (Bhattacharya et al., 2011; Sukmaningsih, 2011). Jamur tiram merupakan salah satu jenis jamur yangmemiliki kandungan protein cukup tinggi dengan lemak yang rendah, dan kadar serat pangan yang tinggi (Muchtadi, 2010). Selain itu, jamur tiram dapat mencegah timbulnya berbagai penyakit, sehingga tepung jamur tiram dapat menjadi alternatif sumber protein nabati yang kaya nutrisi, dan bermanfaat bagi kesehatan (Susanti et al., 2013; Ware, 2014).

Produk tepung dan penyedap rasa jamur tiram masih jarang dijual di pasaran, dan harga jualnya terjangkau karena terbuat dari jamur tiram yang memiliki harga paling ekonomis diantara jenis jamur lainnya, sehingga berpotensi besar untuk dikembangkan. Adanya kegiatan pengabdian ini diharapkan dapat meningkatkan pendapatan petani jamur tiram, dan terbentuk home industry baru yang menyerap banyak tenaga kerja, sehingga turut meningkatkan perekonomian masyarakat sekitar.

\section{METODE PELAKSANAAN}

\section{A. Sosialisasi Program}

Pada kegiatan ini tim pelaksana akan mendatangi lokasi kedua mitra kelompok petani jamur tiram. Tujuannya adalah untuk mengetahui keadaan di lapangan secara langsung, dan melakukan koordinasi dengan kedua mitra mengenai program pengabdian yang akan segera dilaksanakan.

\section{B. Penyuluhan Produksi dan Pengemasan Produk Olahan Jamur Tiram}

Kegiatan ini bertujuan untuk meningkatkan pengetahuan mitra mengenai pengolahan jamur tiram menjadi produk penyedap rasa dan tepung jamur tiram, sekaligus pengemasannya dalam bentuk penyuluhan atau sosialisasi kepada seluruh anggota kelompok petani jamur tiram dari kedua mitra. Materi penyuluhan yang diberikan terkait potensi pengembangan jamur tiram menjadi produk olahan, cara pembuatan penyedap rasa dan tepung jamur tiram, sekaligus cara pengemasan dan pemberian label kemasan. Rincian bahan, alat dan cara pembuatan dijelaskan secara singkat dan sederhana agar mudah dipahami. Peserta juga diberikan pengetahuan strategi untuk memperluas pemasaran produk yang dihasilkan.

\section{Pelatihan Produksi dan Pengemasan Produk Olahan Jamur Tiram}

Kegiatan ini juga diikuti oleh seluruh anggota kelompok petani jamur dari kedua mitra. Pada kegiatan ini akan dilakukan upaya peningkatan keterampilan mitra mengenai pengolahan jamur tiram menjadi produk penyedap rasa dan tepung jamur tiram, sekaligus pengemasannya melalui kegiatan pelatihan. Pada awal kegiatan, peserta akan diajari bagaimana cara pengoperasian alat produksi dan pengemasan. Melalui kegiatan ini diharapkan peserta pelatihan dapat meningkat keterampilannya dengan menjadi peserta yang aktif terlibat secara langsung dalam praktek produksi dan pengemasan produk. 


\section{Pendampingan}

Selama program pengabdian ini berlangsung, kegiatan pendampingan dilakukan pada saat awal dan selama produksi dilaksanakan. Hal ini bertujuan untuk mengetahui dan memastikan apakah kedua mitra sudah dapat melakukan kegiatan produksi secara mandiri dan kontinu. Selain itu, pendampingan juga dilaksanakan selama masa awal pemasaran produk olahan untuk memastikan bahwa kedua mitra dapat menerapkan strategi pemasaran yang tepat, sehingga penjualan produk berjalan lancar.

\section{E. Evaluasi}

Evaluasi program dilakukan antara tim pelaksana dengan kedua mitra dan anggota kelompok petani jamur lainnya melalui diskusi bersama. Pada tahapan ini dilakukan evaluasi seluruh kegiatan yang telah terlaksana mulai dari sosialisasi program hingga pendampingan. Produk olahan yang dihasilkan juga dievaluasi apakah sesuai dengan spesifikasi yang diinginkan dan sesuai dengan minat konsumen di pasaran. Masalah atau kendala yang dihadapi selama proses produksi maupun pemasaran, akan dicari solusinya secara bersama-sama.

\section{III.HASIL DAN PEMBAHASAN}

\section{A. Sosialisasi Program}

Beberapa kegiatan telah dilaksanakan pada kegiatan pengabdian ini. Kegiatan pertama yang dilakukan adalah sosialisasi program kepada mitra kelompok petani jamur tiram "Penambangan" yang ada di Desa Penambangan, Kecamatan Curahdami dan kelompok petani "Veteran" yang ada di Kelurahan Dabasah, Kecamatan Bondowoso.

Kegiatan sosialisasi program pengabdian bertujuan untuk berdiskusi lebih mendalam bersama mitra mengenai usaha pertanian yang selama ini dijalankannya dan solusi diversifikasi produk olahan jamur tiram untuk mengatasi masalah yang selama ini dihadapi petani. Koordinasi juga diperlukan terkait dengan teknologi tepat guna atau peralatan yang akan diterapkan kepada mitra, sehingga dapat disesuaikan dengan kebutuhan mitra untuk mengembangkan usahanya. Selain itu, kegiatan tersebut juga bertujuan untuk menyusun rencana pelaksanaan program pengabdian selanjutnya.

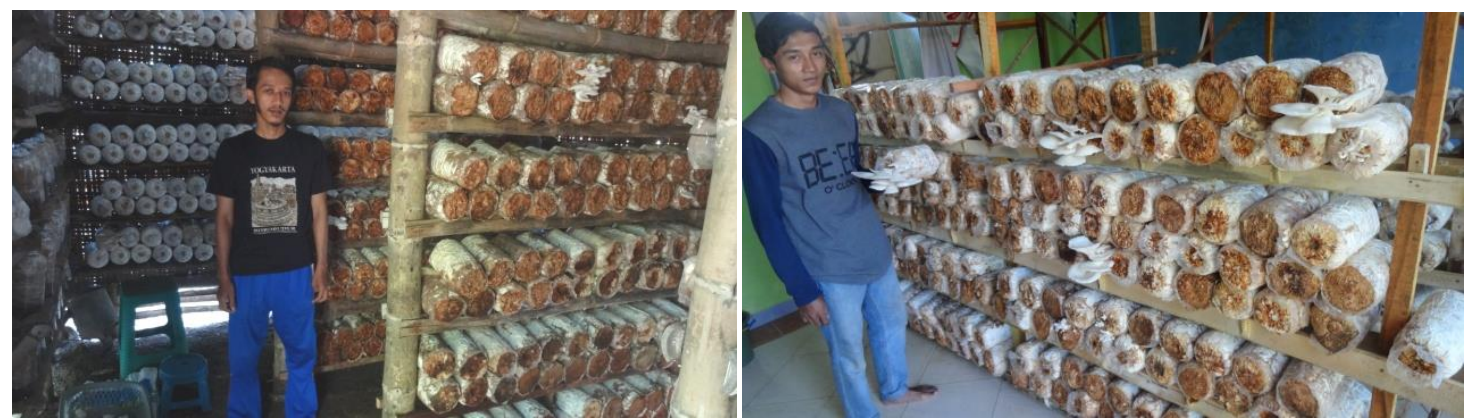

Gambar l. Budidaya jamur tiram yang dilakukan oleh kedua mitra

\section{B. Penyuluhan Produksi dan Pengemasan Produk Olahan Jamur Tiram}

Pada kegiatan penyuluhan, mitra ketua kelompok petani jamur tiram dan anggotanya diberi booklet yang berisi materi mengenai manfaat jamur tiram bagi kesehatan dan potensi pengembangan produknya yang bernilai jual tinggi, bahan-bahan yang perlu disiapkan dan langkah-langkah pembuatan penyedap rasa dan tepung jamur tiram. Tim pelaksana menjelaskan tentang potensi pengembangan produk jamur tiram, yaitu 
penyedap rasa dan tepung jamur tiram sebagai solusi untuk memecahkan permasalahan mitra, terutama terkait masa simpan jamur tiram yang sangat singkat.

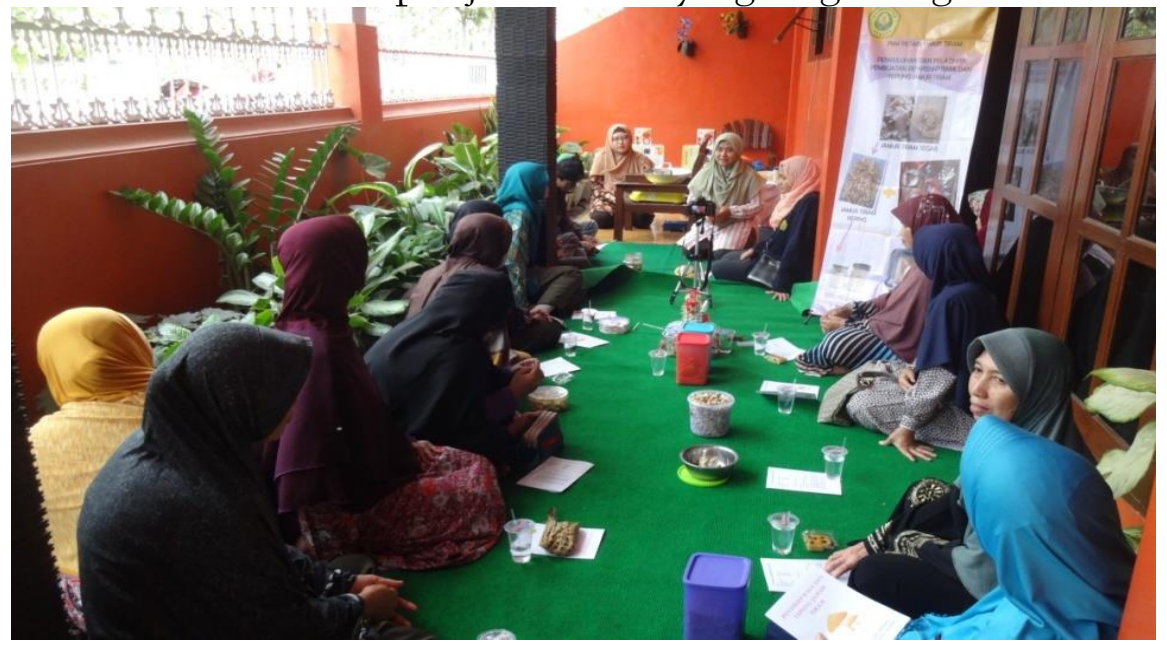

Gambar 2. Kegiatan penyuluhan pengabdian

Saat ini penggunaan penyedap rasa di dalam makanan sangat meluas. Monosodium glutamat (MSG) merupakan penyedap rasa yang paling populer karena dapat meningkatkan persepsi rasa manis dan asin, serta mengurangi rasa asam dan pahit dari makanan (Bhattacharya et al., 2011). Namun, apabila digunakan secara berlebihan dan terus-menerus dapat menyebabkan gangguan lambung, gangguan tidur, mual-mual, reaksi alergi, memicu hipertensi, asma, kanker, diabetes, kelumpuhan, penurunan kecerdasan, dan gangguan spermatogenesis akibat terbentuk radikal bebas dan stress oksidatif pada testis (Sukmaningsih, 2011). Jamur tiram dapat diolah dan menjadi solusi sebagai penyedap rasa alami yang aman, karena memiliki kandungan asam glutamat tetapi rendah sodium dan kalium. Kandungan asam glutamat dalam jamur tiram sebanyak 21,70 mg/g berat kering (Widyastuti et al., 2015).

Jamur tiram memiliki kandungan protein yang tinggi, yaitu 17,5\%-27\% dengan lemak yang rendah 1,6-8\%, dan kadar serat pangan yang tinggi 8-11,5\%. Serat jamur sangat baik untuk pencernaan, sehingga cocok untuk para pelaku diet. Jamur tiram juga bermanfaat bagi konsumsi vegetarian karena mengandung semua asam amino esensial yang dibutuhkan manusia. Kandungan proteinnya bahkan lebih tinggi daripada kedelai tempe yang hanya sebesar 18,3\% setiap $100 \mathrm{~g}$ (Muchtadi, 2010). Selain itu, jamur tiram mengandung mineral, karbohidrat, dan berbagai vitamin. Berdasarkan kandungannya, jamur tiram dapat mencegah timbulnya penyakit hipertensi dan jantung, mengurangi berat badan dan diabetes, antitumor, menyembuhkan anemia, mencegah dan menanggulangi kekurangan gizi, serta pengobatan kekurangan zat besi (Susanti et al., 2013; Ware, 2014). Karenanya, jamur tiram dalam bentuk produk olahan tepung dapat menjadi alternatif sumber protein nabati yang kaya nutrisi, bermanfaat bagi kesehatan, dan ekonomis. Cara mengkonsumsinya adalah dengan menggunakan tepung jamur tersebut sebagai bahan dasar maupun campuran masakan dan makanan ringan, seperti sup, saus, nugget, bakso, siomay, adonan kue dan roti, serta keripik.

\section{Pelatihan Produksi dan Pengemasan Produk Olahan Jamur Tiram}

Kegiatan berikutnya adalah pelatihan pengolahan dan pengemasan jamur tiram. Berdasarkan booklet yang telah dibagikan, para peserta kegiatan pelatihan memulai proses pembuatan penyedap rasa dan tepung jamur tiram dengan bimbingan tim 
pelaksana. Partisipasi mitra dan anggotanya cukup baik. Hal ini ditunjukkan dengan antusiasme mereka dalam mengikuti seluruh kegiatan, termasuk pembuatan penyedap rasa dan tepung jamur tiram.

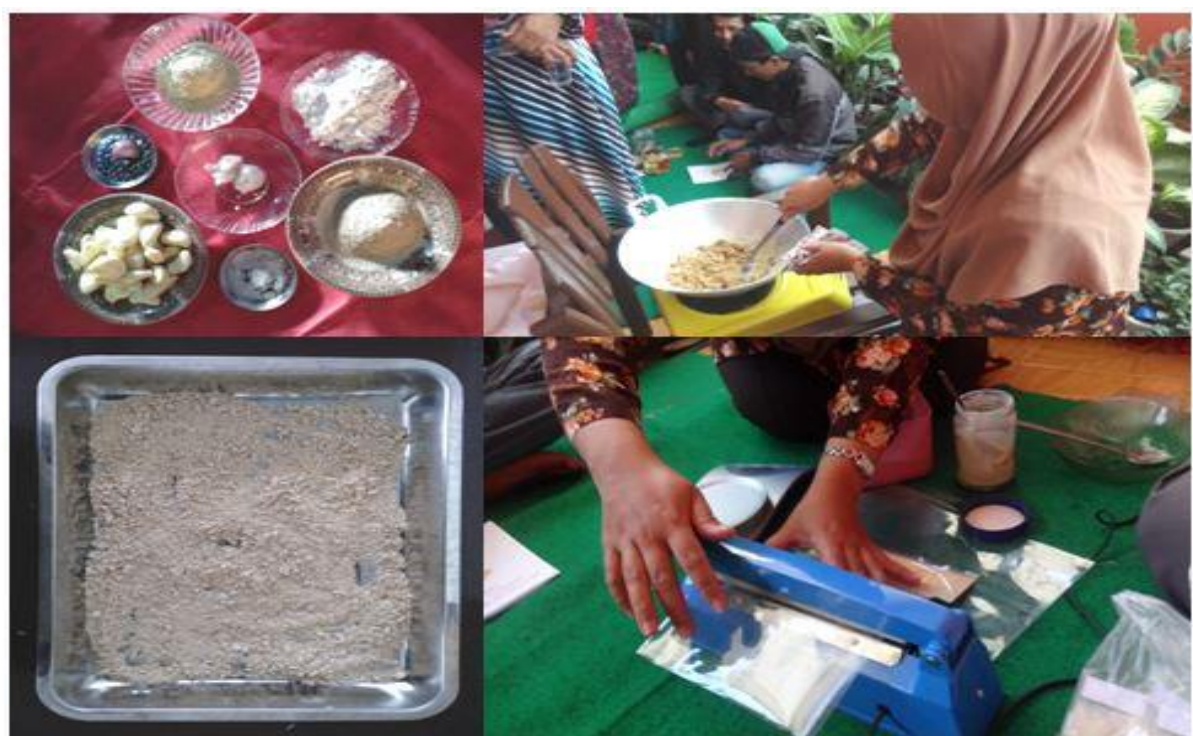

Gambar 3. Kegiatan pelatihan pembuatan penyedap rasa jamur tiram dan pengemasannya

Sebelum proses pengolahan dilakukan, tim pelaksana menyerahkan beberapa peralatan produksi dan pengemasan kepada kedua mitra untuk mendukung pengembangan usaha yang akan dijalankan oleh mitra. Beberapa peralatan yang diberikan adalah oven pengering, blender untuk menghaluskan jamur tiram kering, kompor gas, timbangan, dan lain-lain. Sedangkan untuk pengemasan produk digunakan mesin impulse sealer sebagai perekat kemasan plastik. Adaptasi peralatan dilakukan terhadap kedua mitra dengan mengikutsertakan mitra saat uji coba peralatan. Kegiatan tersebut bertujuan agar kedua mitra dapat mengoperasikan sendiri semua peralatan dengan baik.

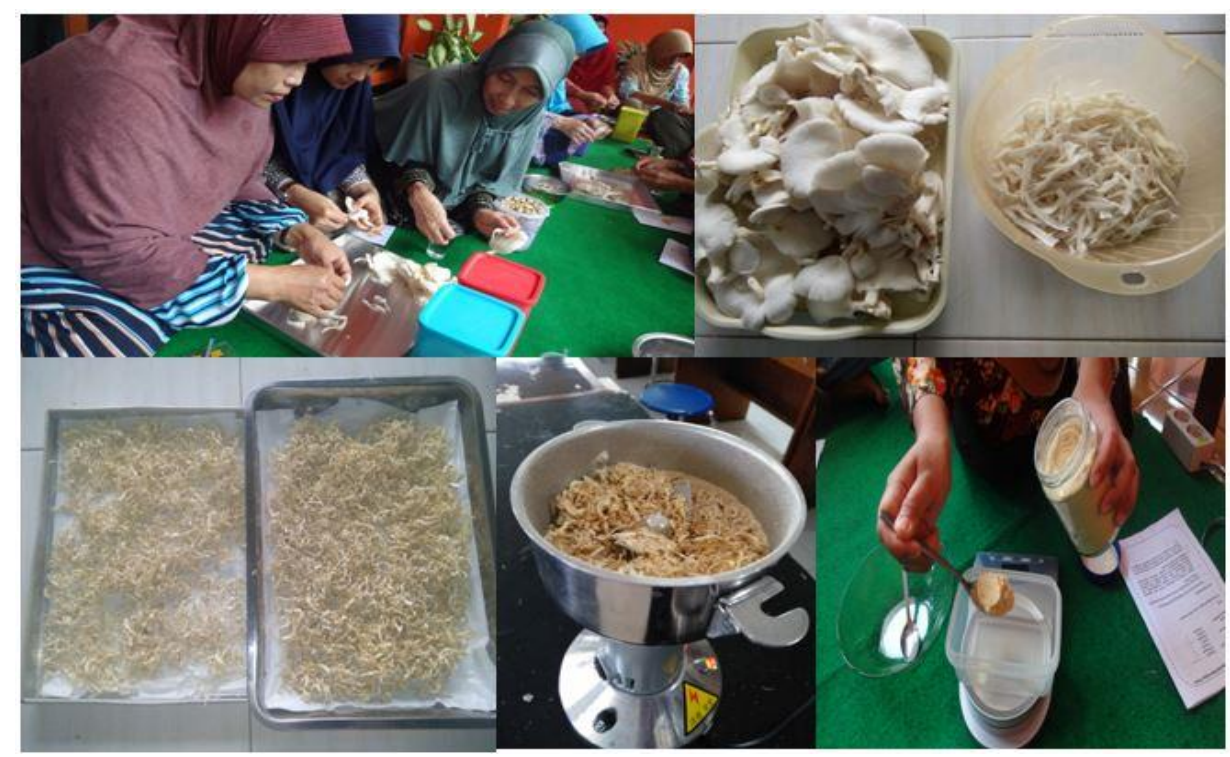

Gambar 4. Kegiatan pelatihan pembuatan tepung jamur tiram 
Selain dilakukan pelatihan mengenai pengolahan jamur tiram menjadi produk penyedap rasa dan tepung jamur tiram, mitra juga dilatih cara pengemasan kedua produk tersebut. Mulai dari jenis bahan pengemas yang dapat mempertahankan kualitas produk hingga pelabelannya agar produk memiliki masa simpan lama disertai tampilan yang menarik. Menurut Kotler \& Armstrong (2012), proses pengemasan mencakup kegiatan membuat desain dan produksi, yang bertujuan untuk melindungi produk agar dapat mempertahankan kualitasnya. Selain itu, kemasan yang baik dapat memberikan ekuitas merek dan meningkatkan penjualan produk. Sedangkan menurut Wijayanti (2012), kemasan memiliki beberapa fingsi, yaitu: a) Memperindah produk dengan penggunaan kemasan sesuai kategori produk, b) Menjamin keamanan produk saat dipajang di tempat penjualan, c) Menjamin keamanan produk saat proses distribusi, d) Memberikan informasi mengenai produk dengan adanya label pada kemasan, e) Sebagai hasil desain dari produk yang menunjukkan produk secara keseluruhan. Dengan kemasan yang menarik, diharapkan dapat meningkatkan omzet penjualan kedua produk tersebut.

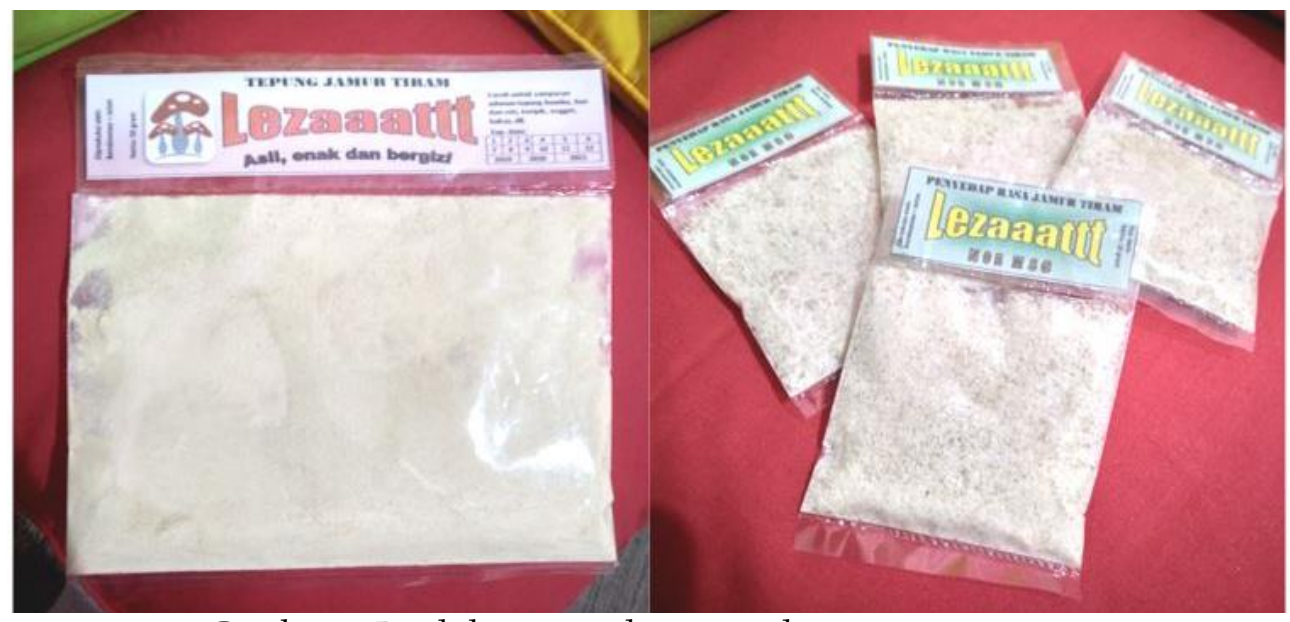

Gambar 5. Produk tepung dan penyedap rasa jamur tiram

\section{Pendampingan}

Tahapan berikutnya adalah dilakukan kegiatan pendampingan untuk mengetahui dan memastikan apakah kedua mitra sudah dapat melakukan kegiatan produksi secara mandiri dan kontinu. Selain itu, pendampingan juga dilaksanakan selama masa awal pemasaran produk olahan untuk memastikan bahwa kedua mitra dapat menerapkan strategi pemasaran yang tepat, sehingga penjualan produk berjalan lancar. Diharapkan kedua mitra dapat melaksanakan kegiatan produksi hingga pemasaran produk penyedap rasa dan tepung jamur tiram secara mandiri setelah kegiatan pengabdian berakhir.

\section{E. Evaluasi}

Pada akhir kegiatan pengabdian ini, dilakukan evaluasi program bersama antara tim pelaksana dan mitra. Hal tersebut bertujuan untuk memastikan bahwa seluruh kegiatan dapat diterima dengan baik oleh kedua mitra. Kegiatan pengabdian ini berperan dalam meningkatkan wawasan mitra mengenai pengembangan usaha berbasis produk pertanian jamur tiram. Adanya pengembangan produk pertanian jamur tiram dapat memberikan nilai tambah, sehingga harga jualnya pun meningkat. Bila produksi berjalan secara kontinu, maka diharapkan dapat meningkatkan pendapatan mitra 
kelompok petani jamur tiram, bahkan masyarakat sekitarnya. Pada saat penjualan produk meningkat, maka dapat dipertimbangkan untuk melakukan pengurusan izin PIRT melalui Dinas Kesehatan setempat. Berdasarkan evaluasi yang telah dilaksanakan, tim pelaksana dan kedua mitra juga sepakat untuk melanjutkan kegiatan pengabdian bila usaha pengolahan jamur tiram mengalami perkembangan.

\section{IV.PENUTUP}

\section{A. Kesimpulan}

Kegiatan penyuluhan dan pelatihan yang disertai pemberian bantuan peralatan produksi dan pengemasan, pendampingan dan evaluasi program, sangat mendukung perkembangan usaha kedua mitra. Dengan diolah menjadi produk yang tahan lama seperti penyedap rasa dan tepung jamur tiram, maka dapat mengatasi permasalahan terkait harga jamur tiram yang rendah dan mudah rusak. Dengan memiliki pengetahuan pemasaran termasuk pengemasan produk, maka kedua mitra dapat menjual produknya secara luas dan kontinyu. Hal ini akan berimbas pada meningkatnya pendapatan petani, bahkan masyarakat sekitarnya.

\section{B. Ucapan Terima Kasih}

Penulis menyampaikan terima kasih kepada Kementerian Ristek Dikti dan LP2M Universitas Jember melalui dukungannya atas kegiatan pengabdian ini melalui Program Kemitraan Masyarakat tahun anggaran 2018 dengan nomor kontrak 996/UN25.3.2/PM/2018.

\section{DAFTAR PUSTAKA}

Bhattacharya, T, Bhakta, A \& Gosh, SK. "Long Term Effect of Monosodium Glutamate in Liver of Albino Mice after Neo-Natal Exposure" (2011) 13:1 Nepal Med Coll J 11.

Kementerian Pertanian Republik Indonesia. Pedoman Teknologi Penanganan Pascapanen Jamur (Jakarta: Kementan RI, 2011).

Kotler, P \& Armstrong, G. "Prinsip-Prinsip Pemasaran” (Jakarta: Erlangga, 2012).

Muchtadi, D. Teknik Evaluasi Nilai Gizi Protein (Bandung: Penerbit Alfabeta, 2010).

Sukmaningsih, AASgA, Ermayanti, IGAM, Wiratmini, NI \& Sudatri, NW. "Gangguan Spermatogenesis Setelah Pemberian Monosodium Glutamat pada Mencit (Mus musculus L.)" (2011) XV:2 Jurnal Biologi 49-52.

Susanti, I, Pranamuda, H, Pradana, A, Agustini, K \& Ranasasmita, R. "Produksi, Karakterisasi Dan Pemanfaatan Ekstrak Beta Glukan Sebagai Anti Tumor" (2013). Seminar Insentif Riset SINAS:Membangun Sinergi Riset Nasional untuk Kemandirian Teknologi.

Ware, M. "Nutrition/Diet: What are the Health Benefits of Mushrooms?', (2014), online: 〈http://www.medicalnewstoday.com/articles/278858.php〉.

Widyastuti, N, Tjokrokusumo, D, Giarni, R. "Potensi Beberapa Jamur Basidiomycota Sebagai Bumbu Penyedap Alternatif Masa Depan” (2015). Prosiding Seminar Agroindustri dan Lokakarya Nasional FKPT-TPI. Program Studi TIP-UTM, 2-3 September 2015.

Wijayanti, T. "Management Marketing Plan” (Jakarta: PT. Elex Media Komputindo, 2012). 